\title{
An EMC Study on Intentional Transmitter of Railway Train Base on Poynting Vector
}

Ping Sun

National Engineering Research Center of Railway Vehicles, CRRC Changchun Railway Vehicles CO., LTD, Changchun, 130062, China.

\begin{abstract}
Base on Poynting Vector to determine the field strength sensitive boundary between the intentional transmitter antenna and the equipment or apparatus installed on railway train. A detail calculation is made to analyse radiation field strength. This paper focuses on how to determine the far field of the rod antenna. By analyzing the radiation field strength of the antenna, it is beneficial to determine the layout design of the antenna on the vehicle at the beginning of the design.
\end{abstract}

Keywords-EMC; intentional Transmitter; poynting vector

\section{INTRODUCTION}

This paper presents a way to determine the boundary of intentional transmitter, which is sensitive to the equipment or apparatus installed on railway train.

Equipment or apparatus installed on railway train complies with the EN 50121-3-2 EMC Standard. The Standard applies to emission and immunity aspects of EMC for electrical and electronic apparatus, and it states the radiated emission requirement in this standard is not intended to be applicable to the intentional transmission from a radio-transmitter as defined by the ITU.

Intentional transmitter is a high field strength source. Near it, the field strength may exceed the equipment's resistance. Base on Poynting Vector, the boundary can be calculated.

The field strength in the near field is complex and not easy to calculate. The field strength in the far field is easy to calculate. This paper focuses on how to determine the far field of the rod antenna.

\section{EN 50121 REQUIREMENTS}

\section{A. Train Unintentional Transmitters Emission Limit}

The train has many electronic and power electronics switching devices which are capable of generating electromagnetic disturbances.

All of the systems on the train are designed and tested to satisfy the limits of EN50121-3-1 and EN50121-3-2:2006.

This limits the radiated emissions for the train and systems below 50kVA are shown in Figure 1.

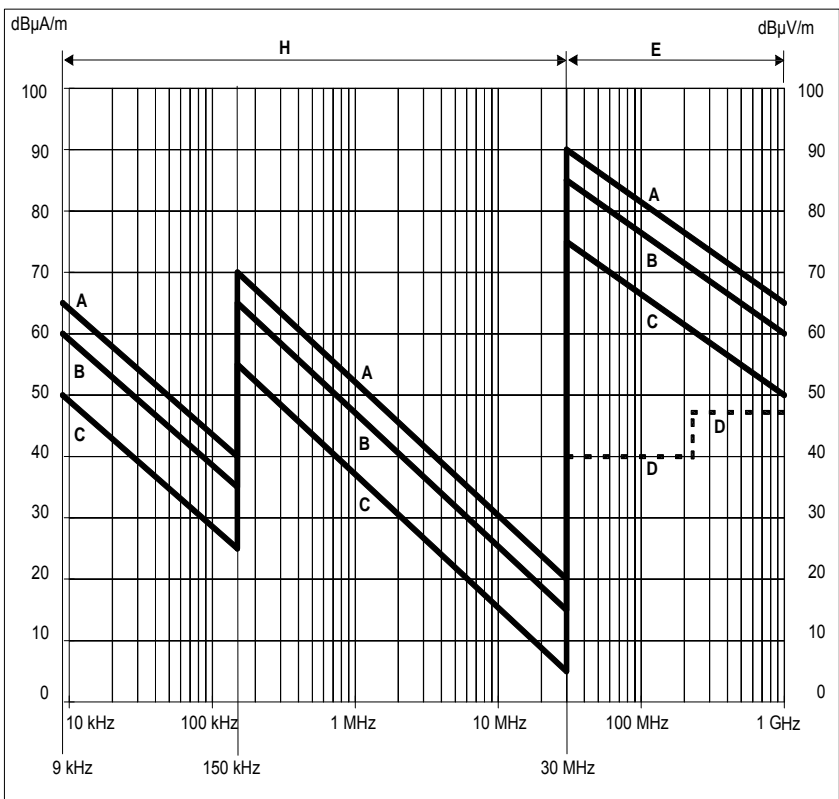

NOTE 1 Emission limits

$A=25 \mathrm{kV}$ a.c.

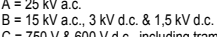

= $=750 \mathrm{~V}$ a $600 \mathrm{~V}$ d.c., including trams/toleybuses for use in city street

Limits for slow moving test(Peak, 10m

FIGURE I. UNINTENTIONAL RADIATED EMISSION LIMITS FOR EQUIPMENT AND TRAIN $[1,2]$

B. Equipment or Apparatus Immunity Level

The Radiated Immunity Level of the equipment or apparatus installed on railway train refers to Table 1. 
TABLE I. RADIATED IMMUNITY LEVEL OF THE EQUIPMENT OR APPARATUS [1]

\begin{tabular}{|c|c|c|c|c|c|c|c|c|}
\hline & $\begin{array}{l}\text { Environmental } \\
\text { Phenomena }\end{array}$ & \multicolumn{2}{|c|}{$\begin{array}{c}\text { Test } \\
\text { specification }\end{array}$} & $\begin{array}{c}\text { Basic } \\
\text { Standard }\end{array}$ & $\begin{array}{l}\text { Test } \\
\text { set-up }\end{array}$ & $\begin{array}{l}\text { Applicabi } \\
\text { lity } \\
\text { note }\end{array}$ & Remarks & $\begin{array}{l}\text { Performa } \\
\text { nce } \\
\text { criteria }\end{array}$ \\
\hline 1 & $\begin{array}{l}\text { Radio-frequency } \\
\text { electromagnetic field. } \\
\text { Amplitude modulated }\end{array}$ & $\begin{array}{l}80 \mathrm{MHz} \text { to } 800 \mathrm{MHz} \\
20 \mathrm{~V} / \mathrm{m}(\mathrm{rms}) \\
80 \% \mathrm{AM}, 1 \mathrm{kHz}\end{array}$ & $\begin{array}{l}\text { Unmodul } \\
\text { ated } \\
\text { carrier }\end{array}$ & $\begin{array}{l}\text { EN } \\
61000-4- \\
3\end{array}$ & $\begin{array}{l}\text { EN } \\
61000-4- \\
3\end{array}$ & $\begin{array}{l}\text { See } a \text { and } \\
b\end{array}$ & $\begin{array}{l}\text { The test level } \\
\text { specified is the } \\
\text { rms value of the } \\
\text { unmodulated } \\
\text { carrier }\end{array}$ & A \\
\hline \multirow{4}{*}{2} & \multirow{4}{*}{$\begin{array}{l}\text { Radio-frequency } \\
\text { electromagnetic field, } \\
\text { from digital } \\
\text { communication } \\
\text { devices }\end{array}$} & $\begin{array}{l}800 \mathrm{MHz} \text { to } 1000 \mathrm{MHz} \\
20 \mathrm{~V} / \mathrm{m} \text { (rms) } \\
80 \% \mathrm{AM}, 1 \mathrm{kHz}\end{array}$ & \multirow{4}{*}{$\begin{array}{l}\text { Unmodul } \\
\text { ated } \\
\text { carrier }\end{array}$} & \multirow{4}{*}{$\begin{array}{l}\text { EN } \\
61000-4- \\
3\end{array}$} & \multirow{4}{*}{$\begin{array}{l}\text { EN } \\
61000-4- \\
3\end{array}$} & \multirow{4}{*}{ See b } & \multirow{4}{*}{$\begin{array}{l}\text { The test level } \\
\text { specified is the } \\
\text { rms value of the } \\
\text { unmodulated } \\
\text { carrier }\end{array}$} & \multirow{4}{*}{ A } \\
\hline & & $\begin{array}{l}1400 \mathrm{MHz} \text { to } 2000 \\
\mathrm{MHz} \\
10 \mathrm{~V} / \mathrm{m} \text { (rms) } \\
80 \% \mathrm{AM}, 1 \mathrm{kHz}\end{array}$ & & & & & & \\
\hline & & $\begin{array}{l}2000 \mathrm{MHz} \text { to } 2700 \\
\mathrm{MHz} \\
5 \mathrm{~V} / \mathrm{m}(\mathrm{rms}) \\
80 \% \mathrm{AM}, 1 \mathrm{kHz}\end{array}$ & & & & & & \\
\hline & & $\begin{array}{l}5100 \mathrm{MHz} \text { to } 6000 \\
\mathrm{MHz} \\
3 \mathrm{~V} / \mathrm{m}(\mathrm{rms}) \\
80 \% \mathrm{AM}, 1 \mathrm{kHz}\end{array}$ & & & & & & \\
\hline $\begin{array}{l}\text { This } \\
\text { nount } \\
\text { For } 1\end{array}$ & $\begin{array}{l}\text { plies to equipment } m \\
\text { other areas a severit } \\
\text { paratus (e.g. traction } \\
\text { nit. In such cases the } \\
\text { t of sub-systems and }\end{array}$ & $\begin{array}{l}\text { ed in the passenger co } \\
\text { el of } 10 \mathrm{~V} / \mathrm{m} \text { may be } \mathrm{u} \\
\mathrm{s} \text {, auxiliary converters } \\
\text { lufacturer should test } \\
\text { assumptions made (e. }\end{array}$ & ments, & $\mathrm{cabo}$ & hhieldi & ing stoc & $\begin{array}{l}\text { f, underframe) } \\
\text { liated electroma } \\
\text { report should j }\end{array}$ & $\begin{array}{l}\text { equipment } \\
\text { c fields on } \\
\text { the }\end{array}$ \\
\hline
\end{tabular}

\section{INTENTIONAL TRANSMITTER}

The key characteristics are detail in Table 2 and Table 3.

The Intentional Transmitter is called Train Radio, it is a Tetra system, which is Terrestrial Enhanced Trunked Radio [4].

TABLE II. TRAIN COMMUNICATION SYSTEM

\begin{tabular}{|c|c|c|c|}
\hline System & \multicolumn{2}{|c|}{ Operating Characteristics } & Additional Information \\
\hline \multirow[t]{10}{*}{ Train Radio System } & Frequency bands & $380-430 \mathrm{MHz}, 407-473 \mathrm{MHz}$ & \multirow{10}{*}{$\begin{array}{l}\text { Tetra system } \\
\text { Located in Cab. } \\
\text { Use of screened coax cable to antenna. }\end{array}$} \\
\hline & Duplex spacing & $5,7,8$, and $10 \mathrm{MHz}$ programmable & \\
\hline & Channel & $25 \mathrm{kHz}$ & \\
\hline & Time multiplexing & TDMA, 4 slots per port & \\
\hline & Digital Modulation & $\pi / 4$ DQPSK & \\
\hline & RF Output Power & $1 \mathrm{~W}$ & \\
\hline & Output impedance & $50 \mathrm{Ohms}$ & \\
\hline & Receiver class & Class $\mathrm{A}$ and $\mathrm{B}$ & \\
\hline & Static Sensitivity & $-112 \mathrm{dBm}$ & \\
\hline & Dynamic Sensitivity & $-103 \mathrm{dBm}$ & \\
\hline
\end{tabular}


TABLE III. TRAIN RADIO ANTENNA

\begin{tabular}{|c|c|c|c|}
\hline System & \multicolumn{2}{|c|}{ Operating Characteristics } & Additional Information \\
\hline \multirow[t]{10}{*}{ Train Radio Antenna } & Frequency range & $410-430 \mathrm{MHz}$ & \multirow[t]{10}{*}{ Located on Roof of Cab. } \\
\hline & Operational bands & S2 & \\
\hline & Bandwidth@ 2:1 VSWR & $5 \%$ & \\
\hline & Gain: Isotropic & $2 \mathrm{dBi}$ & \\
\hline & Compare with $1 / 4$ wave & $0 \mathrm{~dB}$ & \\
\hline & Polarisation & Vertical & \\
\hline & Groundplane & Integrated baseplate Groundplane & \\
\hline & Height & $42 \mathrm{~mm}$ & \\
\hline & Diameter & $160 \mathrm{~mm}$ & \\
\hline & Material & Engineering Plastic & \\
\hline
\end{tabular}

\section{TRAIN RADIO ANALYSIS}

$c=2.997 \times 10^{8} \mathrm{~m} / \mathrm{s} \quad$ Speed of light in a vacuum

$$
f_{1}=410 \times 10^{6} \mathrm{~Hz} \quad f_{2}=430 \times 10^{6} \mathrm{~Hz} \quad \text { Upper }
$$

and lower bounds antenna frequency Tetra range

$f=410 \times 10^{6} \mathrm{~Hz}$ Lower bound of frequency in use antenna by Tetra system

$\lambda=c / f$ Calculation of wavelength

$$
\lambda=0.731 m \text { and } \lambda / 4=0.183 m
$$

The Transition Boundary between Reactive/Radiating Field is calculated from solution of the Raleigh function for practical antennas (ones with finite length) it is found to be $\lambda / 4$.

$$
\lambda / 4=0.183 m \quad \lambda / 2 \pi=0.116 m
$$

The diameter of antenna shroud: diameter $=160 \mathrm{~mm}$ radius $=$ diameter $/ 2=0.08 m$

From inspection of the antenna the maximum linear dimension of the antenna is the length $D=42 m m=0.042 m$

The transition between near field and far field for a practical (finite) antenna is found by $2 D^{2} / \lambda=0.004826 m$ Ref 3.4 .5

As $2 D^{2} / \lambda<\lambda / 4$, for the antenna ,the far Field will use $\lambda / 2 \pi=0.116 m .[3,5]$

In order to calculate the Electric Field Strength versus distance a variable for distance must be defined.

$n=1: 1000$ Index for array variables

$$
r_{n}=(n / 100+0.1) m \text { Distance variable } r_{n} \text { for }
$$
$0.11 \mathrm{~m}$ to $10 \mathrm{~m}$ in $10 \mathrm{~mm}$ step

Power

$$
P w r=1 W \quad \text { Train Radio System RF Output }
$$

The Poynting Vector can be used to find the radiated Power Density $\mathrm{S}$ of an infinitesimal isotropic antenna. It also holds true for any antenna when the distance is large compared to the antenna dimensions (in wavelength terms) and providing the directive/gain is taking into account.

\section{A. The Poynting Vector}

$S=$ Power / Area In the case of an isotropic antenna it radiates equally in all directions hence the area is the surface of a sphere $4 * \pi *$ radius $^{2}$

$$
\begin{aligned}
& \text { Gain }=10^{(2 / 20)} \quad \text { Convert Gain from } \mathrm{dB} \\
& \text { EIRP }=\text { Pwr * Duty } * \text { Gain Radiated Power } \\
& S_{n}=\operatorname{EIRP} /\left(4 * \pi * r_{n}^{2}\right)
\end{aligned}
$$
Density

In Free Space, the characteristic impedance $\eta_{0}=120 * \pi \Omega$

$$
E_{n}=\sqrt{S_{n}^{*} \eta_{0}}
$$

\section{Electric Field Strength}

A SCILAB program is used to implement the above calculation. 


\section{REFERENCES}

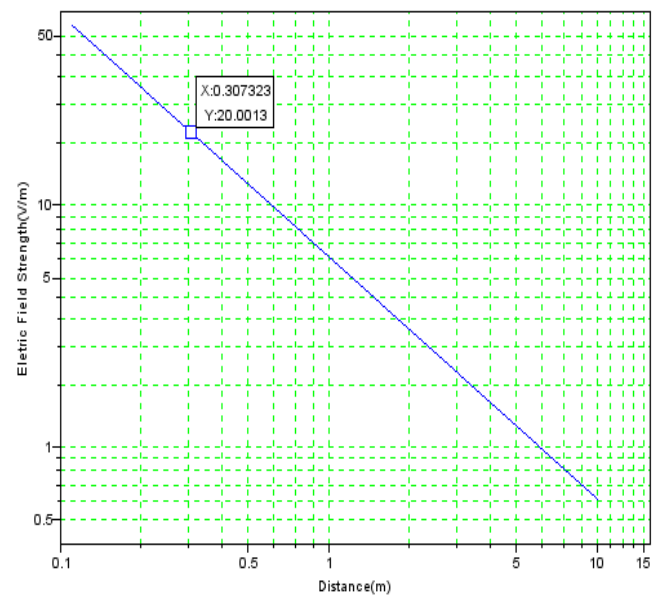

FIGURE II. ELECTRIC FIELD STRENGTH VERSUS DISTANCE FOR TRAIN RADIO ANTENNA

As the frequency is $410 \mathrm{MHz}$, refer to Table 1 , the Radiated Immunity Level of the equipment or apparatus is $20 \mathrm{~V} / \mathrm{m}$.

Finding the Boundary at which $20 \mathrm{~V} / \mathrm{m}$ is exceeded using the Poynting vector from Figure 2.

$$
r=0.30732 \mathrm{~m}=307.32 \mathrm{~mm}
$$

An analysis of the trainborne radio installation shows that the $20 \mathrm{~V} / \mathrm{m}$ field strength threshold is reached at a distance of $0.307 \mathrm{~m}$ from the centre of the antenna on the top surface of the train. Below top surface of the train radio antenna the field strength will be significant lower due to the antenna polarization. The electrical and electronic equipments on the train have been designed against $20 \mathrm{~V} / \mathrm{m}(146 \mathrm{~dB} \mu \mathrm{V} / \mathrm{m})$ field strength in the train radio frequency range according to EN 50121-3-2, and it should also be noted that the peak field strength in EN50121-3-2 is actually $36 \mathrm{~V} / \mathrm{m}$ due to the $80 \%$ Amplitude Modulation. And the location of antenna is away from any emissive equipment on top surface of the train.

\section{SUMMARY}

By analyzing the radiation field strength of the antenna, it is beneficial to determine the layout design of the antenna on the vehicle at the beginning of the design.
[1] EN 50121-3-2:2015 Railway applications - Electromagnetic Compatibility Part 3-2 Rolling Stock Apparatus.

[2] EN 50121-3-1:2006 Railway applications - Electromagnetic Compatibility Part 3-1 Train and complete vehicle.

[3] BS EN 50383-2002 Basic standard for the calculation and measurement of electromagnetic field strength and SAR related to human exposure from radio base stations and fixed terminal stations for wireless telecommunications system (110 MHz 40-GHz)

[4] ETSI TS 100 392-15 V1.5.1 (2011-02) Terrestrial Trunked Radio (TETRA); Voice plus Data (V+D); Part 15: TETRA frequency bands, duplex spacings and channel numbering.

[5] Dipak L. Sengupta, Valdis V. Lipepa, Applied Electromagnetics and Electromagnetic Compatibility Hoboken, New Jersey, 2006 